\title{
POTENTIAL FOR CLIMATE CHANGE TO INCREASE CONTAMINANTS EXPOSURE AND EFFECTS IN GYRFALCONS
}

\author{
Angela Matz ${ }^{1}$, Ted Swem ${ }^{1}$, Philip Johnson ${ }^{2}$, Travis Booms ${ }^{3}$, and Clayton White ${ }^{4}$ \\ ${ }^{1}$ US Fish and Wildlife Service, 101 12th Avenue, Room 110, \\ Fairbanks, AK 99701,USA. E-mail: angela_matz@fws.gov \\ ${ }^{2}$ US Fish and Wildlife Service, 1011 E. Tudor Road, Anchorage AK 99503, USA \\ ${ }^{3}$ Alaska Department of Fish and Game, Wildlife Diversity Program, 1300 College Road, \\ Fairbanks, AK 99701, USA \\ ${ }^{4}$ Brigham Young University, Department of Plant and Wildlife Sciences and Monte L. Bean Life \\ Science Museum, Provo, UT 84602, USA
}

\begin{abstract}
Climate change is a global pollution issue with the potential to affect raptor populations at scales greater than those caused by the last great contaminant threat, DDT. Climate change effects are already apparent in northern ecosystems, including those where Gyrfalcons (Falco rusticolus) breed. A changing climate may influence contaminant fate and transport, release contaminants currently stored in abiotic media such as permafrost soils, and increase natural resource extraction, transportation, and other human activities in northern systems that were previously less accessible. Of particular concern for raptors are the potential liberation of sequestered persistent pollutants from melting glaciers and permafrost, increased methylation of mercury in wetlands formed by thawing permafrost, and increased deposition of emerging persistent organic pollutants to polar areas via changes in wind and ocean transport. We found low levels of persistent organic pollutants and metals, including mercury, in eggs and feathers of Gyrfalcons from western Alaska, reviewed current and historical data on contaminants in Gyrfalcons, their prey, and their habitats, and hypothesized scenarios whereby contaminants levels that are currently of low concern could increase and affect Gyrfalcon breeding populations. In particular, switching to greater proportion of aquatic or higher-trophic level prey from ptarmigan (Lagopus spp.) will increase concentrations of mercury and persistent organic pollutants in breeding Gyrfalcons, with potential subsequent effects on populations. Received 28 July 2011, accepted 5 August 2011.
\end{abstract}

Matz, A., T. Swem, P. Johnson, T. Booms, And C. White. 2011. Potential for climate change to increase contaminants exposure and effects in Gyrfalcons. Pages 161-176 in R. T. Watson, T. J. Cade, M. Fuller, G. Hunt, and E. Potapov (Eds.). Gyrfalcons and Ptarmigan in a Changing World, Volume I. The Peregrine Fund, Boise, Idaho, USA. http://dx.doi.org/10.4080/gpcw.2011.0115

Keywords: Gyrfalcon, Falco rusticolus, climate change, contaminants, mercury. 
SigNIFICANT NEGATIVE EFFECTS on raptor populations during the last century have resulted from many human activities, including intentional (e.g., pesticide) and unintentional (e.g., industrial byproduct) contaminant releases. Indeed, the widespread use of dichlorodiphenyltrichloroethane (DDT) and other environmentally persistent organochlorine pesticides resulted in the near-extinction of multiple raptor species in North America and western Europe. Global climate change, another significant ecological event linked to anthropogenic release of chemicals (IPCC 2007) could rival DDT as the greatest contaminants threat ever faced by raptors at high latitudes.

Most of the observed increase in global average temperatures since the mid- $20^{\text {th }}$ Century is very likely due to observed increases in anthropogenic greenhouse gas concentrations (IPCC 2007). Global atmospheric concentrations of carbon dioxide $\left(\mathrm{CO}_{2}\right)$, methane $\left(\mathrm{CH}_{4}\right)$, and nitrous oxide $\left(\mathrm{N}_{2} \mathrm{O}\right)$ have increased markedly as a result of human activities since 1750 and now far exceed pre-industrial values, as determined from ice cores. Global increases in $\mathrm{CO}_{2}$ concentrations are due primarily to fossil fuel use, with land-use change providing a significant but smaller contribution. Increased $\mathrm{CH}_{4}$ concentrations are very likely due to agriculture and fossil fuel use, and increased $\mathrm{N}_{2} \mathrm{O}$ concentrations are primarily attributed to agriculture (IPCC 2007).

The mechanism of DDT toxicity to raptors was relatively direct (eggshell thinning) compared to the large array of hypothesized exposure and effect scenarios associated with climate change. For example, we do not anticipate direct effects of the industrial pollutants contributing to climate change, such as $\mathrm{CO}_{2}$. Instead, changes in climate may affect the mobilization, transport, and availability of toxic contaminants, particularly persistent organic pollutants (POPs) and mercury, to biota including raptors, and cause changes in food webs that may influence biomagnification of persistent pollutants.
Arctic and sub-arctic ecosystems are currently undergoing a system-wide response to an altered climatic state (Hinzman et al. 2005) affecting physical and biological processes. Projected increases in temperature will enhance contaminant influxes to aquatic systems, and increase the susceptibility of aquatic organisms to contaminant exposure and effects, resulting in higher contaminant loads and biomagnification in ecosystems (ACIA 2005). Climate change also has the potential to alter the primary and secondary release of persistent organic pollutants, alter food webs and alter exposure of human and wildlife populations to these contaminants (UNEP/AMAP 2011). Temperature changes fundamentally influence contaminant fate and transport, since water solubility and propensity for atmospheric transport of contaminants are mediated by temperature. In general, under warmer climatic conditions, chemicals will more readily partition from soil to air, increasing the amount of atmospheric transport and net transport to the Arctic (AMAP 2003).

Erosion rates in coastal Alaska and along some major river systems have increased dramatically in recent years and other sites have experienced encroachment by surface waters. These changes threaten release of pollutants from contaminated sites such as landfills and drilling mud pits. The containment of contaminated sites which depend on permafrost stability such as sewage lagoons, dumps, tailings ponds, and oil-contaminated soils are at risk from loss of permafrost (AMAP 2003, Macdonald et al. 2005). Permafrost loss can also affect pollutant transport, resulting in a shift toward dendritic drainage patterns that will allow more efficient transport of contaminants into ponds and lakes and possibly re-mobilize contaminants entrained in tundra soils (Macdonald et al. 2005).

Persistent Organic Pollutants.-Glacial ice mass is currently shrinking due to climate warming (Hinzman et al. 2005), which can release contaminants accumulated over many 
years of deposition (Blais et al. 1998). Glacial streams contain unusually high proportions of persistent organic pollutants in solution, because of the low potential for these compounds to adsorb to suspended sediments in the glacial stream, which are characterized by low organic matter content. The prevalence of organochlorine compounds in the dissolved phase (rather than being tightly bound to suspended sediments), coupled with the low dissolved organic carbon concentrations in the lake water, indicates a high potential for bioavailability of these compounds to aquatic biota (Blais et al. 2001).

In 2005, Bettinetti et al. (2008) observed a sharp increase in p'p'-DDT and its metabolites in Zebra Mussels (Dreissena polymorpha) and fish from two glacier-fed southern alpine lakes in Italy. Total DDT (the parent compound plus metabolites) in Zebra Mussels were more than 150 times higher than 2003 levels, and concentrations in pelagic fish exceeded the Italian safety threshold for human consumption. The authors concluded that glacial meltwater was the main cause of the pollution peak observed in biota of downstream lakes (Bettinetti et al. 2008). Other studies in the Alps have found chlorinated pesticide concentrations (HCHs and DDTs) in a glacial stream to be about one order of magnitude higher than a stream in a non-glacial catchment (Bizzotto et al. 2009a) and contaminant concentrations in macroinvertebrates from the glacial-fed stream were generally higher, but more variable, than in the non-glacial stream (Bizzotto et al. 2009b). Dated sediment cores from a glacier-fed lake in Switzerland showed high organochlorine concentrations in the 1960s-1970s, when atmospheric inputs were greatest. Concentrations decreased in the 1980s-1990s, with a sharp increase in recent years. Current inputs to the lake are similar to those from the peak air emission years, with the exception of total DDT and $\gamma-\mathrm{HCH}$, which exhibit flux rates that exceed past inputs by factors of five and two, respectively (Bogdal et al. 2009). Subsequent dated sediment core sampling in paired catchments conducted at a similar altitude only $8 \mathrm{~km}$ apart, confirmed these results. Cores from a glaciated system showed a bimodal concentration pattern (peak air emissions and recent glacial melt) while the non-glaciated catchment showed a single peak during peak air emission periods (Schmid et al. 2011). Meltwater from glaciers may contribute high concentrations of pesticides to cold aquatic ecosystems for decades or centuries (Donald et al. 1999).

Mercury.-Northern peatlands accumulate organic carbon and contaminants such as mercury, sometimes over thousands of years. Sampling of peat cores from a Swedish mire and nearby lake sediment cores show that during past periods of warming (e.g., 1400s to mid1500 s), lake sediment mercury concentrations increased due to transport of organic matter and mercury (Rydberg et al. 2010). Current thawing of permafrost is again increasing themokarst erosion, resulting in a wetter mire and transport of mercury to the lake. Rydberg et al. (2010) concluded that while these observations are from a single site, climate-related erosion of organically rich mires have the potential to influence mercury levels in other freshwater ecosystems within the subarctic and Arctic and mercury dynamics should be studied in other systems. Similar observations have been made for lead in subarctic Sweden, with increased transport of lead to lakes in areas experiencing permafrost melt, and lesser transport in boreal or birch-forest catchment lakes (Klaminder et al. 2010).

If Arctic precipitation increases as predicted, mean annual river discharge will also increase - by about $20 \%$ for the Yenisei, Lena and Mackenzie Rivers (Macdonald et al. 2005), causing increased contaminant flux, particularly of mercury. In the Mackenzie River system in Canada, Leitch et al. (2007) found high concentrations of mercury in marine mammals and other biota in the river delta and Beaufort Sea were positively correlated with river flow, with increased mercury concentrations that may in part reflect 
increased surface inundation and bank erosion. Mercury concentrations were also greatest during spring freshets and high flow events. For the period 2003-2005, the mercury flux from the Mackenzie River to the Beaufort Sea averaged 2.2 tons/yr (and $15 \mathrm{~kg} / \mathrm{yr}$ of methylmercury), the largest known mercury source to the Beaufort Sea, and freshet season discharges accounted for more than $50 \%$ of the annual mercury flux (Leitch et al. 2007). Unfortunately, spring - freshet season - coincides with a period of high marine biological activity, which results in increased potential for biota to be exposed to mercury. Climate-related hydrological changes presumably will also affect large Russian rivers that carry significant contaminant loads and flow to the Arctic Ocean (e.g., Zhulidov et al. 2000, Carroll et al. 2008).

The fire data record for Alaska suggests an increase in large fires in response to recent climate warming (ACIA 2005). While the record is insufficient to determine definitively whether the increase is outside the range of natural variability, various models predict that a warming climate will lead to more and larger fires, and that warmer and wetter scenarios will produce more very large fires compared to the warmer and dryer scenarios. The warmer and dryer climate scenario resulted in more frequent medium-sized fires, which prevented fuels from building up across the landscape and limited the number of large fires (ACIA 2005). Recent data show a significantly increasing trend in total area burned within Alaska and Canada over the past 30 years, and both fire frequency and severity are expected to increase in northern boreal forests with continued climate change (Flannigan et al. 2009). Of special concern for boreal raptors, Friedli et al. (2009) suggested that increasing temperatures in boreal regions, where the largest global soil mercury pool resides, will exacerbate regional and global mercury emissions due to more frequent, larger, and more intense wildfires.
The association of mercury emissions with wildfires is well studied. For example, Turetsky et al. (2006) found that mercury formerly sequestered in cold, wet peat soils was released to the environment during fires in Canadian boreal forests, which presented a growing threat to aquatic habitats and northern food chains as the climate warms. Estimates of circumboreal mercury emissions presented in this study are 15 -fold greater than estimates that did not account for mercury stored in peat soils. Boreal areas with greater peatland abundance are correlated with the size of large fire events (Flannigan et al. 2009). Weidinmeyer and Friedli (2007) estimated mercury emissions from wildfires in Alaska and the lower 48 States from 2002-2006 to average 44 metric tons per year, roughly equivalent to $30 \%$ of the total mercury emissions permitted by the US Environmental Protection Agency in 2002. In 2004, a high fire year, fire-related mercury emissions in Alaska (32 metric tons) exceeded the combined total amount from the lower 48 states (23 metric tons) (Weidinmeyer and Friedli 2007). Both total and methyl mercury have been found to increase in passive precipitation collectors following fires in northern Minnesota, with post-fire methyl mercury concentrations up to 8.75 times higher than the pre-burn average and even greater deposition in conifer-dominated areas (Witt et al. 2009).

These documented and predicted post-fire mercury increases raise concern over potential impacts to lakes, streams and wetland areas surrounding wildfires (Witt et al. 2009). Mercury concentrations in fish have been shown to increase following fires in Alberta, Canada (Kelly et al. 2006), by increasing mercury inputs and more importantly by restructuring food webs through greater productivity and increasing piscivory, with a 5-fold increase in whole-body mercury accumulation in Rainbow Trout (Oncorhynchus mykiss). Collectively, these studies suggest that fire-related mercury emissions, with the potential to impact aquatic biota and those who feed on them, will continue or increase with a warming climate. 
Mercury is of particular concern in the Arctic since numerous studies have shown stable or increasing temporal trends in biota, including Gyrfalcons (Falco rusticolus) (Dietz et al. 2006). Macdonald et al. (2005) suggested that physical factors such as ice cover, permafrost melting and organic carbon cycling may be driving these observations, since gaseous mercury concentrations have not shown similar changes. Mercury dynamics are particularly complex in the Arctic, as well documented mercury depletion events associated with the spring "polar sunrise" result in a pulse of mercury to wetland systems, which foster methylation of mercury, in turn increasing its bioavailability (Lindberg et al. 2002, Loseto et al. 2004). Increased temperature, greater organic loadings and increased lake productivity may enhance bioaccumulation of methylmercury through increased methylation and reduced photodegradation (Hammerschmidt et al.2006). Aquatic food webs in the Arctic are further susceptible to changes in mercury inputs because methylmercury biomagnifies readily, exhibiting a 1000- to 3000fold concentration increase from particulate organic matter to apex predators in some systems (AMAP 2003).

While North American mercury emissions have declined with time, overall global mercury emissions are projected to rise as more coal-fired facilities are built in Asia, a region directly upwind of the Bering Sea, Alaska, and the Western Arctic. In 2000, the largest emissions of mercury to the global atmosphere occurred from combustion of fossil fuels, mainly coal in utility, industrial, and residential boilers. As much as two-thirds of the total emission of approximately 2190 tons of mercury emitted from all anthropogenic sources worldwide in 2000 came from combustion of fossil fuels (Pacyna et al. 2006). Emissions of mercury from coal combustion are between one and two orders of magnitude higher than emissions from oil combustion, depending on the country. Asian countries contributed about $54 \%$ to the global mercury emissions from anthropogenic sources in 2000. China had the highest mercury emissions from anthropogenic activities, contributing about $28 \%$ of the global emissions of mercury in 2000 (Pacyna et al. 2006). Approximately $45 \%$ of the mercury emissions in China in 1999 came from nonferrous metals smelting, $38 \%$ from coal combustion, and $17 \%$ from miscellaneous activities, of which battery and fluorescent lamp production and cement production are the largest contributors (Streets et al. 2005).

Ecological Shifts.-Climate change is already affecting, and will continue to affect, contaminant fate, transport, and mobility in Arctic and subarctic systems. However, increased ecosystem loading will not necessarily affect an individual species, unless the changes are manifest within the species' own ecological niche. The Hutchinsonian niche, an n-dimensional space occupied by a species within its ecosystem and defined by the axes of abiotic and biotic vectors that influence birth and death rates (Holt 2009), is a useful construct for evaluating species response to rapid environmental change (Holt 2009), such as increased pollution. The abiotic axis of contaminant loadings in the ecosystem will likely change with increasing Arctic temperatures and other physical factors, but will climate-change induced alterations in biotic vectors shift the Gyrfalcon's realized niche and result in increased contaminant exposure and effects for Gyrfalcons?

For example, aquatic food webs often contain greater concentrations of contaminants than do co-located terrestrial food webs, because an aquatic system can concentrate contaminants found throughout an entire watershed. Were Gyrfalcons diet to change to include a much greater proportion of aquatic species (e.g., waterfowl) from their current primary prey base of terrestrial ptarmigan, we may expect increased exposure and effects from persistent contaminants. This would occur with declines in ptarmigan populations, such as might be expected with greater human access and hunting. Also, any diet change that would elevate 
trophic status would allow for greater contaminant accumulation, such as from herbivorous to piscivorous prey (e.g., from ptarmigan to fish-eating waterfowl or seabirds). A third relevant prey base change is the potential to eat more migratory prey, which themselves are exposed to greater contaminant loadings by virtue of spending time in areas of the globe which have far greater relative inputs from industrial and agricultural sources.

Changes in arctic and subarctic food webs are already occurring, with implications for consumers at higher trophic levels. Some authors have investigated climate-driven changes in aquatic productivity, suggesting increased scavenging of mercury from the water column by algae or suspended detrital algal matter (the algal-mercury scavenging hypothesis) (Outridge et al. 2007, Stern et al.2009), although the existence of this phenomenon has been questioned (Kirk et al. 2011).

Climate-mediated changes in productivity have in turn been related to increased mercury concentrations in Daphnia-dominated zooplankton communities (Chételat and Amyot 2009) and Burbot (Lota lota) over a 20+ year period despite declining atmospheric inputs (Carrie et al. 2010). Increased primary production has also been invoked to explain increased population size at Northern Fulmar (Fulmarus glacialis) colonies in the Canadian high arctic and associated increases in contaminants concentrations (Michelutti et al. 2009).

Productivity may not be the only ecological variable influencing climate-mediated changes in contaminants uptake. For example, climaterelated changes in timing of sea ice breakup have been linked to Polar Bear (Ursus maritimus) dietary variation in western Hudson Bay, Canada (McKinney et al. 2009). Between 1991 and 2007 , an increase in consumption of open-water seals relative to ice-associated seals (particularly Bearded Seals Erignathus barbatus) was inferred by stable isotope and fatty acid analyses. These dietary shifts have in turn influenced con- taminants concentrations in Polar Bear adipose tissue, with an increase in most contaminants such as PCBs, PBDEs and chlordanes, but a decrease in DDT (McKinney et al. 2009).

In general, contaminant concentrations in Gyrfalcons have always been relatively low compared to other raptors, because their main prey, ptarmigan, are terrestrial, resident, and low on the food chain (herbivorous) (Cade et al. 1971, Walker 1977). Where Gyrfalcons have used alternative prey - marine, migratory, or trophically elevated (e.g., insectivorous or piscivorous), their persistent contaminant concentrations were higher (Lindberg 1984, Jarman et al. 1994, Ólafsdóttir et al. 1995, Ólafsdóttir et al. 2001). In this paper, we used historical and current data on contaminant concentrations in Gyrfalcons and life history characteristics (trophic status and habitat use) to hypothesize climate changemediated alterations in the ecological niche of Gyrfalcons, particularly those nesting in Alaska, that could result in increased contaminant exposure and effects.

\section{Methods}

We collected and analyzed addled eggs, molted adult feathers, nestling feathers, and blood, liver and kidney from one dead juvenile, and the whole body of one newly hatched chick, at Gyrfalcon nest sites within the Yukon Delta National Wildlife Refuge in southwestern Alaska, 2004-2007, under all appropriate State and Federal permits. Samples came from three distinct study areas: the Askinuk Mountains, the Volcanoes, and the Kilbuk Mountains (described in McCaffery et al. 2011, this volume).

Addled (unhatched) eggs were collected several weeks after the expected hatch date or after siblings had hatched. In the field, eggs were wrapped in chemically clean foil, placed in padded containers, and kept cool until contents could be removed under laboratory conditions. Egg contents, and liver and kidney from one juvenile found dead, were removed 
using chemically clean instruments and placed in chemically clean jars (I-Chem Series 300), then stored at $-20^{\circ} \mathrm{C}$ until overnight shipment on ice to the analytical laboratory. Whole blood was collected via brachial venipuncture and stored frozen in glass tubes with sodium or lithium heparin additive (Vacutainer or equivalent, Fisher Scientific). Whole breast feathers were plucked from approximately 25-day-old nestlings and stored in Longmire's buffer for DNA extraction; after extraction, the remainder of the sample was sent to the laboratory for analysis, along with samples of the buffer solution (in which $\mathrm{Hg}$ was not detected). Whole molted adult feathers were collected at or directly below nests.

Feathers and blood were analyzed for total $\mathrm{Hg}$. Kidney, liver, eggs, and the newly hatched chick were analyzed for a suite of metals and metalloids (trace elements), including $\mathrm{Al}, \mathrm{As}$, $\mathrm{B}, \mathrm{Ba}, \mathrm{Cd}, \mathrm{Cr}, \mathrm{Cu}, \mathrm{Fe}, \mathrm{Hg}, \mathrm{Mg}, \mathrm{Mn}, \mathrm{Mo}, \mathrm{Ni}$, $\mathrm{Pb}, \mathrm{Se}, \mathrm{Sr}, \mathrm{V}$, and $\mathrm{Zn}$. Liver and eggs were analyzed for persistent organic pollutants, mostly organochlorine pesticides and metabolites (aldrin; alpha, beta, delta, gamma, and total BHC; alpha and gamma chlordane; cis- and trans-nonachlor; total DDT and seven metabolites; dieldrin, endosulfan I, II, and sulfate; endrin; heptachlor and heptachlor epoxide; mirex; and toxaphene), and total and congenerspecific polychlorinated biphenyls (PCBs). One egg was analyzed for total and congenerspecific brominated diphenyl ethers (BDEs).

Mercury analyses on blood and feathers were done at Alpha Woods Hole Labs and Research Triangle Institute, Research Triangle Park, NC. Briefly, feather samples were homogenized using a food processor. A portion of the samples was freeze dried for determination of moisture content and ground to 100 mesh with a mill. In a microwave oven, $0.25-0.5 \mathrm{~g}$ of freeze-dried sample was heated in a capped 120 $\mathrm{ml}$ Teflon vessel in the presence of $5 \mathrm{ml}$ nitric acid (Baker Instr-Analyzed) for three minutes at 120 watts, three minutes at 300 watts, and fifteen minutes at 450 watts. The residue was then diluted to $50 \mathrm{ml}$ with laboratory pure water. Approximately $0.25 \mathrm{~g}$ of samples was introduced into a Milestone DMA-80 Mercury Analyzer. The sample was dried and chemically decomposed at $750^{\circ} \mathrm{C}$ under an oxygen atmosphere, liberating any mercury in the samples. The mercury vapor was collected selectively on a gold amalgam surface. The amalgamator was rapidly heated to $800^{\circ} \mathrm{C}$ and the oxygen flow carried the mercury vapor through an absorption cell where the $\mathrm{Hg}$ absorbance (as a function of $\mathrm{Hg}$ concentration) was measured at $253.7 \mathrm{~nm}$. Other samples were analyzed using cold vapor atomic fluorescence spectroscopy, where tissue samples were homogenized, and approximately $1 \mathrm{~g}$ was digested by hot plate in aqua regia. An aliquot of the digestate was prepared with $\mathrm{HCl} / \mathrm{BrCl}$ and hydroxylamine hydrochloride solution. Mercury in the digested sample was reduced to elemental mercury, aerated from solution, and introduced into the spectrophotometer. The emission was measured and compared to a multi-level initial calibration for quantification.

Metal analyses were done at Alpha Woods Hole Labs, Woods Hole, MA by inductively coupled plasma-mass spectroscopy. Solid samples (approximately $1 \mathrm{~g}$ ) were digested by hot plate or microwave according to EPA Method 3050 (hot plate) or EPA Method 3051 (microwave). An aliquot of digestate was nebulized into a spray chamber where a stream of argon carried the sample aerosol through a quartz torch and injected into the radio frequency inductively coupled plasma. The ions produced in the plasma were introduced to the mass spectrometer for quantification against a multi-level initial calibration.

Organic analyses were done at Geochemical and Environmental Research Group, Texas A\&M University, College Station, TX, and TDI Brooks International, College Station, TX. Tissue samples were extracted by the NOAA Status and Trends Method (MacLeod et al. 1985) with minor revisions (Brooks et al. 1989, Wade et al. 1988). Samples were 
homogenized with a Tissumizer (Teledyne Tekmar, Mason, OH). A 1 to 10-g sample (wet weight) was extracted by adding surrogate standards, $\mathrm{Na}_{2} \mathrm{SO}_{4}$, and methylene chloride in a centrifuge tube. The tissue extracts were purified by silica/alumina column chromatography to isolate the aliphatic and the PAH/pesticide/PCB fractions. The PAH/pesticide/PCB fraction was further purified by high-performance liquid chromatography (HPLC) to remove interfering lipids. The quantitative analyses were performed by capillary gas chromatography (CGC) with an electron capture detector for pesticides and PCBs, with confirmation and co-eluents (including Endosulfan 1 and PCB congeners 114 and 157) analyzed by CGC with a mass spectrometer detector in the SIM mode. Quantification was based on the primary ion, and two additional masses for each analyte were also monitored for verification of the peak identification. The masses were based on EPA protocols such as EPA 680 for PCBs and 8270c for pesticides.

Descriptive statistics were calculated for commonly detected and toxic contaminants in Arctic-breeding raptors (e.g., Ambrose et al. 2000) including mercury $(\mathrm{Hg})$, cadmium $(\mathrm{Cd})$, lead $(\mathrm{Pb}), \mathrm{DDT}$ and metabolites, and PCBs. We report arithmetic means and standard deviation, calculated with any data less than the limit of detection (<LOD) substituted with $0.5 \mathrm{x}$ the LOD (since a small number of such substitutions are unlikely to affect estimation of summary statistics; Gibbons 1994). The unit of analysis was the nest, such that data from eggs or nestlings from the same nest were pooled prior to statistical analysis, since persistent contaminant concentrations are often correlated in raptor eggs or nestlings from the same nest. In general, because of low detection rates and low sample sizes, these data were not amenable to statistical analyses, although we were able to compare $\mathrm{Hg}$ concentrations in adult and nestling feathers using ANOVA, with alpha = 0.05 . All summary statistics and statistical analyses were done using SYSTAT 13 (Systat Software, Inc., Chicago, IL).

\section{RESUltS}

We analyzed nestling feather samples from nine separate nests; molted adult feathers from eight separate nests; 21 nestling blood samples from 17 nests (four nests were sampled twice in two years); organs from one juvenile; eggs from three separate nests; and one newly hatched nestling.

Comparison of total $\mathrm{Hg}$ in our samples to concentrations of concern for birds showed that all total $\mathrm{Hg}$ concentrations were below published toxic thresholds (Table 1). However, adult feathers had significantly greater $\mathrm{Hg}$ concentrations than did nestling feathers (mean $+\mathrm{SD}$ of $0.41(+0.21)$ and $0.13(+0.08)$, respectively; $p=0.002)$. Blood and feather samples were numerous enough to compare among breeding areas; mean $\mathrm{Hg}$ values from the Askinuk Mountains study area were greater than those from the Volcanoes and Kilbuk study area (Figure 1).

Cadmium was analyzed and not detected in eggs $(\mathrm{n}=3$, LOD $0.22 \mathrm{mg} / \mathrm{kg} \mathrm{dw})$ or in the newly hatched chick (LOD $0.13 \mathrm{mg} / \mathrm{kg} \mathrm{dw}$ ), and was detected at low levels in the kidney $(0.49 \mathrm{mg} / \mathrm{kg} \mathrm{ww})$ and liver $(0.28 \mathrm{mg} / \mathrm{kg} \mathrm{ww})$. Toxic effects for hepatic, renal, or testicular toxicity in avian species were estimated to begin at $45 \mathrm{mg} / \mathrm{kg}$ in liver, and a $50 \%$ probability of toxicity at $66 \mathrm{mg} / \mathrm{kg}$ in kidney (Wayland and Scheuhammer 2011). Lead was not detected in eggs, liver, or kidney (LOD 0.03, 0.03 , and $0.02 \mathrm{mg} / \mathrm{kg} \mathrm{ww}$, respectively).

When persistent organic pollutants were detected in eggs, concentrations were generally low (Table 2). The most commonly detected DDT metabolite, and one that is largely responsible for eggshell thinning - p,p'-DDE - and total PCBs were each an order of magnitude below concentrations that had adverse effects on productivity of wild birds (Blus 2011, Harris and Elliot 2011). There were no BDEs detected in the one egg in which they were analyzed (total BDE limit of detection $0.046 \mathrm{mg} / \mathrm{kg} \mathrm{ww}$ ). 
Table 1. Mean (+ SD) or actual total mercury $(\mathrm{Hg})$ concentrations $(\mathrm{mg} / \mathrm{kg}$, dry weight except where noted) in Gyrfalcons (Falco rusticolus) from Alaska, USA, 2004-07, compared to avian concentrations of concern.

\begin{tabular}{|c|c|c|}
\hline Sample Type & $\mathrm{Hg}(\mathrm{mg} / \mathrm{kg})$ & Concentration of Concern, Effects \\
\hline Nestling feathers $(n=9)$ & $0.13(+0.08)$ & $\begin{array}{l}>1-5 \mathrm{mg} / \mathrm{kg} \text {, various effects, including } \\
\text { description as "background"1-3 }\end{array}$ \\
\hline Adult feathers $(n=8)$ & $0.41(+0.21)$ & $40.0 \mathrm{ug} / \mathrm{g}$, flight feather asymmetry ${ }^{4}$ \\
\hline Nestling whole blood $(n=21)$ & $0.038(+0.041)^{5}$ & $3.0 \mathrm{ug} / \mathrm{g}$ in adults, reproductive failure ${ }^{4}$ \\
\hline $\operatorname{Egg}(n=3)$ & $0.16,0.15,<0.10$ & $\begin{array}{l}0.6 \mathrm{mg} / \mathrm{kg} \text {, adverse effects in } 95 \% \text { of avian } \\
\text { species }^{6}\end{array}$ \\
\hline $\begin{array}{l}\text { Juvenile }(n=1) \\
\text { Liver } \\
\text { Kidney }\end{array}$ & $\begin{array}{l}0.23^{5} \\
0.17^{5}\end{array}$ & $\begin{array}{l}18.4-127 \mathrm{mg} / \mathrm{kg} \mathrm{ww} \text {, death } \\
76 \mathrm{mg} / \mathrm{kg} \mathrm{ww} \text {, death }\end{array}$ \\
\hline Nestling, newly hatched $(n=1)$ & 0.28 & $\begin{array}{l}0.6 \mathrm{mg} / \mathrm{kg} \text {, adverse effects in } 95 \% \text { of avian } \\
\text { species }^{6}\end{array}$ \\
\hline
\end{tabular}

${ }^{1}$ Scheuhammer 1991.

${ }^{2}$ Berg et al. 1996.

${ }^{3}$ Lindberg 1984.

${ }^{4}$ Evers et al. 2008

${ }^{5}$ Wet weight; percent moisture not available due to small sample volume.

${ }^{6}$ Shore et al. 2011.
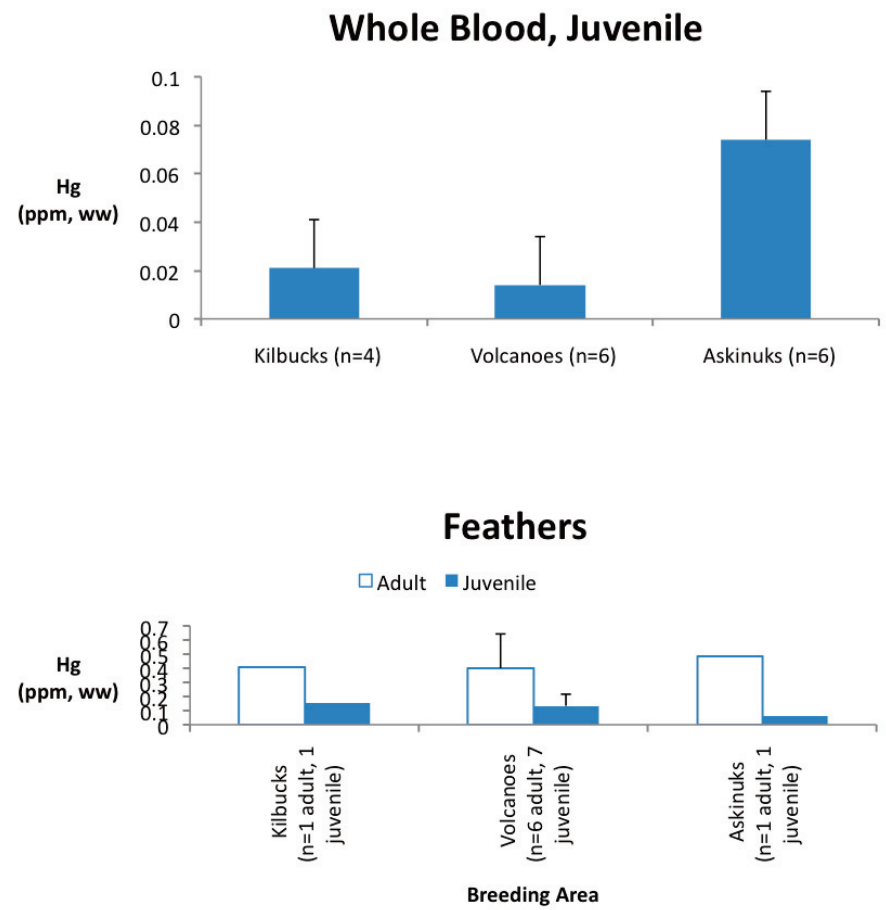

Figure 1. Mean mercury concentrations in Gyrfalcon samples (a. in nestling whole blood and $b$. feathers) from three breeding areas in southwestern Alaska, USA, 2005-07. All three breeding areas were located within the Yukon Delta National Wildlife Refuge, but Gyrfalcons in the Askinuk Mountains study area consumed a greater proportion of waterfowl in their diet compared to Gyrfalcons in the Volcanoes and Kilbuck Mountains breeding areas. 
Table 2. Arithmetic mean (+ SD) concentrations (mg/kg wet weight) of organic contaminants detected in three Gyrfalcon (Falco rusticolus) eggs from Alaska, 2005-2007.

\begin{tabular}{ll} 
Analyte & Mean (SD) \\
\hline beta BHC & $0.013(0.014)$ \\
HCB & $0.016(0.018)$ \\
heptachlor epoxide & $0.003(0.003)$ \\
Mirex & $0.004(0.004)$ \\
Oxychlordane & $0.008(0.009)$ \\
p,p'-DDE & $0.040(0.042)$ \\
Total PCBs & $0.211(0.184)$ \\
\hline
\end{tabular}

\section{DISCUSSION}

Persistent contaminant loadings in Gyrfalcon samples from southwestern Alaska were relatively low. Because nestling feather samples were not collected according to standard protocol (i.e., they were stored in buffer rather than stored dry), nestling feather data on $\mathrm{Hg}$ should not be considered definitive. However, the low concentrations are mirrored in all other samples, including adult feathers, nestling blood, and eggs, so our overall conclusion of low $\mathrm{Hg}$ concentrations in Gyrfalcons breeding in southwestern Alaska is supported.

$\mathrm{Hg}$ concentrations and concentrations of other persistent contaminants in Gyrfalcons from Alaska were lower than those reported in Peregrine Falcons (Falco peregrinus) breeding in Alaska. For example, $\mathrm{Hg}$ concentrations in addled Peregrine eggs averaged 1.5-2.0 $\mu \mathrm{g} / \mathrm{kg}$ dry weight (Ambrose et al. 2000), a conclusion consistent with Cade et al. (1971). Peregrines also had greater concentrations of persistent contaminants compared to Gyrfalcons in West Greenland (Jarman et al. 1994) and Sweden (Lindberg 1984), because Peregrines consume more aquatic, migratory, and non-herbivorous prey.

As expected, adult Gyrfalcons had greater concentrations of mercury in feathers than did nestlings, because mercury accumulates within individuals over time. The same difference in $\mathrm{Hg}$ concentrations between adult and nestling Gyrfalcons was documented in Gyrfalcons nesting in Sweden in 1972-77 by Lindberg (1984).

The three southwest Alaska study areas, which are located within approximately 200 miles of each other, nevertheless differ in proportion of prey (McCaffery et al. 2011, this volume). In the Askinuk Mountains, which had greater mercury concentrations in nestling blood $-\mathrm{a}$ site-specific indicator - Gyrfalcons consume proportionally more migratory birds such as waterfowl compared to the other study areas. 
In the Volcanoes breeding area, Gyrfalcons eat almost exclusively ptarmigan, and Kilbuck Mountain-nesting Gyrfalcons eat primarily ptarmigan and ground squirrels (McCaffery et al. 2011, this volume). These differences, observed within relatively close breeding areas, emphasize the importance of diet in predicting, evaluating, or mitigating contaminant exposure and effects in Gyrfalcons.

For example, Lindberg (1984) found that $\mathrm{Hg}$ concentrations were greater in Swedish Gyrfalcon nestlings that were fed even a small amount of aquatic prey such as waterfowl and shorebirds, compared to those eating mostly ptarmigan (Lagopus spp.). Even a 10\% change (biomass-based) from Tetraonidae to Anatidae, Charadriidae, Solopacidae, or Laridae prey species resulted in an order of magnitude increase in $\mathrm{Hg}$ concentrations (from 0.03 to 1.2 mean feather $\mathrm{Hg} /$ nest ( $\mathrm{n}=2$ nests, with two nestlings in each nest). Of nine prey species analyzed for pectoral muscle $\mathrm{Hg}$ concentrations, Lagopus spp. had undetectable concentrations, while Common Greenshanks (Tringa nebularia), somewhat piscivorous waders, had mean pectoral muscle $\mathrm{Hg}$ concentrations of $0.44 \mathrm{ug} / \mathrm{kg} \mathrm{dw}$ ) (Lindberg 1984).

In Iceland, where Gyrfalcons had greater concentrations of persistent organic pollutants (Ólafsdóttir et al. 1995), even though eating primarily ptarmigan (Nielsen and Cade 1990), Ólafsdóttir et al. (2001) analyzed prey species and found PCBs and DDTs in increasing concentrations from resident terrestrial species (Rock Ptarmigan Lagopus muta), to resident freshwater (Mallard Anas platyrhynchos), to migratory freshwater (Tufted Duck Aythya fuligula and Golden Plover Pluvialis apricaria), to migratory coastal (Purple Sandpiper Calidris maritima) to resident marine species (Black Guillemot Cepphus grylle). They concluded that Icelandic Gyrfalcons received most of their persistent organochlorine burdens from marine and migratory prey.
These examples, along with our data, support the basic ecotoxicological argument that Gyrfalcons preying primarily on resident terrestrial ptarmigan have relatively low and non-toxic body burdens of persistent contaminants. A small change in diet, however, can result in much higher concentrations, particularly of mercury, as demonstrated by Lindberg (1984).

Persistent organochlorine contaminants have declined in Arctic-nesting birds of prey and have been banned from use. Mercury, however, has in some cases increased (Ambrose et al. 2000, Dietz et al. 2006). Therefore, to the extent that climate change results in changes in Gyrfalcon diet, particularly to aquatic or migratory prey, we may expect that Gyrfalcon contaminant loadings will also increase. We also expect to see increases in mercury and persistent contaminants in Icelandic Gyrfalcons, which already prey on seabirds, as pollutant transport to the Arctic is increased.

\section{ACKNOWLEDGMENTS}

The US Fish and Wildlife Service supported many aspects of this study. In particular, the Environmental Contaminants Program supported analysis of Gyrfalcon samples for contaminants, the Fairbanks Fish and Wildlife Field Office supported A. Matz and T. Swem during the preparation of this manuscript, and the Yukon Delta National Wildlife Refuge supported T. Booms' field work to collect samples for contaminants analysis. T. Booms was also supported by a US Environmental Protection Agency (EPA) Science to Achieve Results Graduate Fellowship. The EPA has not officially endorsed this publication and the views expressed herein may not reflect the views of the EPA. We also thank Rick Watson and Grainger Hunt for their editorial review. 


\section{Literature Cited}

Ambrose, R. E., A. Matz, T. Swem, And P. BENTE. 2000. Environmental contaminants in American and Arctic Peregrine Falcon eggs in Alaska, 1979-95. US Fish and Wildlife Service Technical Report NAESTR-00-02, Ecological Services Fairbanks, Alaska, USA.

ACIA. 2005. Arctic Climate Impact Assessment. Cambridge University Press, Cambridge, UK.

AMAP. 2003. AMAP Assessment 2002: The Influence of Global Change on contaminant pathways to, within, and from the Arctic. Arctic Monitoring and Assessment Programme (AMAP), Oslo, Norway.

Berg, W., A. Johnels, B. SJostrand, AND T. Westermark. 1996. Mercury content in feathers of Swedish birds from the past 100 years. Oikos 17:71-83.

Bettinetti, R., S. Quadroni, S. Galassi, R. BACChETTA, L. BonARdi, AND G. VAILATI. 2008. Is meltwater from Alpine glaciers a secondary DDT source for lakes? Chemosphere 73:1027-1031.

Bizzotto E. C., S. Villa, C. Vaj, and M. VIGHI. 2009a. Comparison of glacial and non-glacial-fed streams to evaluate the loading of persistent organic pollutants through seasonal snow/ice melt. Chemosphere 74:924-30.

Bizzotto, E. C., S. Villa, and M. Vighi. 2009b. POP bioaccumulation in macroinvertebrates of alpine freshwater systems. Environmental Pollution 157:3192-3198.

Blais, J. M., D. W. Schindler, D. C. G. Muir, L. E. Kimpe, D. B. Donald, ANd B. RosenBERG. 1998. Accumulation of persistent organochlorine compounds in mountains of western Canada. Nature 395:585-588.

Blais, J. M., D. W. Schindler, D. C. G. Muir, M. Sharp, D. Donald, M. LAFrenière, E. Braekevelt and W. M. J. Strachan. 2001. Melting Glaciers: A major source of persistent organochlorines to subalpine Bow Lake in Banff National Park, Canada. Ambio 30:410-415.
BLus, L. J. 2011. DDT, DDD, and DDE in birds. Pages 425-446 in W. N. Beyer and J. P. Meador (Eds.). Environmental Contaminants in Biota. CRC Press, Boca Raton, Florida, USA.

Bogdal, C., P. Schmid, M. ZennegG, F. S. Anselmetti, M. Scheringer, AND K. HungerbHLER. 2009. Blast from the past: Melting glaciers as a relevant source for persistent organic pollutants. Environmental Science and Technology 43:8173-8177.

Brooks, J. M., T. L. Wade, E. L. Atlas, M. C. Kennicutt II, F. J. Presley, R. R. Fay, E. N. Powell, AND G. WolfF. 1989. Analysis of bivalves and sediments for organic chemicals and tract elements. Third Annual Report for NOAA's National Status and Trends Program, Contract 50-DGNC-500262.

Cade, T. J., J. L. Lincer, C. M. White, D. G. Roseneau, AND L. G. SWARTZ. 1971. DDE residues and eggshell changes in Alaskan falcons and hawks. Science 172:955-957.

Carroll, J., V. Savinov, T. Savinova, S. Dahle, R. McCrea, and D. C. G. Muir. 2008. PCBs, PBDEs and pesticides released to the Arctic Ocean by the Russian Rivers $\mathrm{Ob}$ and Yenisei. Environmental Science and Technology 42:69-74.

Carrie, J., F. Wang, H. SAnei, R. W. MaCDONALD, P. M. OUtRIDGE, AND G. A. STERN. 2010. Increasing contaminant burdens in an Arctic fish, Burbot (Lota lota), in a warming climate. Environmental Science and Technology 44:316-322.

Chételat, J., AND M. Amyot. 2009. Elevated methylmercury in High Arctic Daphnia and the role of productivity in controlling their distribution. Global Change Biology 15:706-718.

Dietz, R., F. F. Riget, D. Boertmann, C. Sonne, M. T. Olsen, J. FJeldsÅ, K. FalK, M. Kirkegaard, C. Egevang, G. Asmund, F. Wille, ANd S. Mǿller. 2006. Time trends of mercury in feathers in West Greenland birds of prey during 1851-2003. Environmental Science and Technology 40:5911-5916. 
Donald, D. B., J. Syrgiannis, R. W. Crosley, G. Hodsworth, D. C. G. Muir, B. RosenBerg, A. Sole, and D. W. Schindler. 1999. Delayed deposition of organochlorine pesticides at a temperate glacier. Environmental Science and Technology 33:1794-1798.

Evers, D. C., L. J. Savoy, C. R. DeSorbo, D. E. YATES, W. HANSON, K. M. TAYlor, L. S. Siegel, J. H. CoOley, JR., M. S. BANK, A. Major, K. Munney, B. F. Mower, H. S. Vogel, N. Schoch, M. PoKras, M. W. Goodale, AND J. Fair. 2008. Adverse effects from environmental mercury loads on breeding Common Loons. Ecotoxicology 17:69-81.

FlanNigan, M., B. StOcks, M. TURETSKy, AND M. Wotton. 2009. Impacts of climate change on fire activity and fire management in the circumboreal forest. Global Change Biology 15:549-560.

Friedli, H. R., A. F. AREllano, S. CinNiRElla, AND N. PIRRONE. 2009. Initial estimates of mercury emissions to the atmosphere from global biomass burning. Environmental Science and Technology 43:3507-3513.

GibBons, R. D. 1994. Statistical Methods for Groundwater Monitoring. John Wiley \& Sons, New York, USA.

Hammerschmidt, C. R., W. F. Fitzgerald, C. H. LAmborG, P. H. Balcom, AND C .M. TSENG. 2006. Biogeochemical cycling of methylmercury in lakes and tundra watersheds of arctic Alaska. Environmental Science and Technology 40:1204-1211.

HARRIS, M. L., AND J. E. ElLIOTT. 2011. Effects of polychlorinated biphenyls, dibenzo-pdioxins and dibenzofurans, and polybrominated diphenyl ethers in wild birds. Pages 477-530 in W. N. Beyer and J. P. Meador (Eds.). Environmental Contaminants in Biota. CRC Press, Boca Raton, Florida, USA.

Hinzman, L. D., N. D. Bette, W. R. Bolton, F. S. Chapin, M. B. Dyurgerov, C. L. Fastie, B. Griffith, R. D. Hollister, A. Hope, H. P. Huntington, A. M. Jensen, G. J. Jia, T. Jorgenson, D. L. Kane, D. R.
Klein, G. Kofinas, A. H. Lynch, A. H. Lloyd, A. D. McGuire, F. E. Nelson, W. C. Oechel, T. E. Osterkamp, C. H. Racine, V. E. Romanovsky, R. S. Stone, D. A. Stow, M. Strum, C. E. Tweedie, G. L. Vourlitis, M. D. Walker, D.A. Walker, P. J. Webber, J. M. Welker, K. S. WINKER, AND K. YOSHIKAWA. 2005. Evidence and implications of recent climate change in northern Alaska and other Arctic regions. Climatic Change 72:251-298.

Holt, R. D. 2009. Bringing the Hutchinsonian niche into the $21^{\text {st }}$ century: Ecological and evolutionary perspectives. Proceedings of the National Academy of Sciences 106 (Suppl. 2):19659-19665.

IPCC (InTERgovernmental PANEl ON Climate Change). 2007. Climate Change 2007: Synthesis Report.

Jarman, W. M., S. A. Burns, W. G. Mattox, AND W. S. SEEGAR. 1994. Organochlorine contaminants in the plasma of Peregrine Falcons and Gyrfalcons nesting in Greenland. Arctic 47:334-340.

Kelly, E. N., D. W. Schindler, V. L. ST. Louis, D. B. Donald, AND K. E. Vladicka. 2006. Forest fire increases mercury accumulation by fishes via food web restructuring and increased mercury inputs. Proceedings of the National Academy of Sciences 103:19380-19385.

KLAMINDER, J., D. HAMMARLUND, U. KoKFELT, J. E. VonK, AND C. Bigler. 2010. Lead contamination of subarctic lakes and its response to reduced atmospheric fallout: Can the recovery process be countered by the ongoing climate change? Environmental Science and Technology 44:2335-2340.

KirK, J. L., D. C. M. Muir, D. Antoniades, M. S. V. Douglas, M. S. Evans, T. A. JACKSON, H. Kling, S. LAMOUREUX, D. S. S. Lim, R. Pienitz, J. P. SMOL, K. Stewart, X. WANG, AND F. YANG. 2011. Climate change and mercury accumulation in Canadian high and subarctic lakes. Environmental Science and Technology 45:964-970.

Leitch, D. R., J. CARrie, D. LEAN, R. W. MaCDONALD, G. A. STERN, AND F. WANG. 2007. 
The delivery of mercury to the Beaufort Sea of the Arctic Ocean by the Mackenzie River. Science of the Total Environment 373:178-195.

LINDBERG, P. 1984. Mercury in feathers of Swedish Gyrfalcons, Falco rusticolus, in relation to diet. Bulletin of Environmental Contamination and Toxicology 32:453459.

LindberG, S. E., S. Brooks, C. J. Lin, K. J. Scott, M. S. Landis, R. K. Stevens, M. Goodsite, AND A. Richter. 2002. Dynamic oxidation of gaseous mercury in the Arctic troposphere at polar sunrise. Environmental Science and Technology 36:1245-1256.

Loseto, L. L, S. D. Sicliano, And D. R. S. LEAN. 2004. Methylmercury production in high Arctic wetlands. Environmental Toxicology and Chemistry 23:17-23.

Macdonald, R. W., T. Harner, J. Fyfe, T. F. BidDLEMAN, AND J. P. STOW. 2005. Recent climate change in the Arctic and its impacts on contaminant pathways and interpretation of temporal trend data. Science of the Total Environment 342:5-86.

MacLeod, W. D., D. W. Brown, A. J. FriedMAN, D. G. Burrow, O. Mayes, R. W. Pearce, C. A. Wigren, AND R. G. Bogar. 1985. Standard Analytical Procedures of the NOAA National Analytical Facility 1985-86. Extractable Toxic Organic Compounds, $2^{\text {nd }}$ ed. US Dept. of Commerce, NOAA/NMFS, NOAA Tech. Memo. NMFS F/NWRC-92.

MCCAFFERY, B. J., T. L. Booms, T. C. J. Doolittle, F. Broerman, J. R. Morgart, AND K. M. Sowl. 2011. The ecology of Gyrfalcons Falco rusticolus on the YukonKuskokwim Delta, Alaska. In R. T. Watson, T. J. Cade, M. Fuller, G. Hunt, and E. Potapov (Eds.). Gyrfalcons and Ptarmigan in a Changing World. The Peregrine Fund, Boise, Idaho, USA. http://dx.doi.org/ 10.4080/gpcw.2011.0117

McKinney, M. A., E. Peacock, and R. J. LETCHER. 2009. Sea ice-associated diet change increases the levels of chlorinated and brominated contaminants in Polar
Bears. Environmental Science and Technology 43:4334-4339.

Michelutti, N., B. E. Keatley, S. Brimble, J. M. Blais, H. Liu, M. S. V. Douglas, M. L. Mallory, R. W. Macdonald, And J. P. SMOL. 2009. Seabird-driven shifts in Arctic pond ecosystems. Proceedings of the Royal Society-B: Biological Sciences 276 (1656):591-596.

Nielsen, Ó. K., And Cade, T. J. 1990. Seasonal changes in food habits of Gyrfalcons in NE-Iceland. Ornis Scandivanica 21:202211.

Ólafsdóttir, K., Æ. Petersen, S. ThÓRDARDÓTTIR, AND T. JÓHANNESSON. 1995. Organochlorine residues in Gyrfalcons (Falco rusticolus) in Iceland. Bulletin of Environmental Contamination and Toxicology 55:382-389.

Ólafsdóttir, K., Æ. Petersen, E. V. MaGNÚSDÓTTIR, T. BJÖRNSSON, AND T. JÓHANNESSON. 2001. Persistent organochlorine levels in six prey species of the Gyrfalcon Falco rusticolus in Iceland. Environmental Pollution 112:245-251.

Outridge, P. M, H. SAnei, G. A. Stern, P. B. Hamilton, ANd F. Goodarzi. 2007. Evidence for control of mercury accumulation rates in Canadian high arctic lake sediments by variations of aquatic primary productivity. Environmental Science and Technology 41:5259-5265.

Pacyna, E. G., J. M. PACyna, F. SteEnhuisen, AND S. WILSON. 2006. Global anthropogenic mercury emission inventory for 2000. Atmospheric Environment 40:40484063.

RYDBERG, J., J. KlAMinder, P. Rosén, AND R. BINDLER. 2010. Climate driven release of carbon and mercury from permafrost mires increases mercury loading to sub-arctic lakes. Science of the Total Environment 408:4778-4783.

SCHEUHAMMER, A. M. 1991. Effects of acidification on the availability of toxic metal and calcium to wild birds and mammals. Environmental Pollution 71:329-375. 
Schmid, P., C. Bogdal, N. BlÜthgen, F. S. Anselmetti, A. ZWyssig, AND K. HungerbHLER. 2011. The missing piece: Sediment records in remote mountain lakes confirm glaciers being secondary sources of persistent organic pollutants. Environmental Science and Technology 45:203208.

Shore, R. F., M. G. Pereira, L. A. Walker, AND D. R. Thompson. 2011. Mercury in non-marine birds and mammals. Pages 609-626 in W. N. Beyer and J. P. Meador (Eds.). Environmental Contaminants in Biota. CRC Press, Boca Raton, Florida, USA.

Stern, G. A., H. SAnei, P. Roach, J. Delaronde, and P. M. Outridge. 2009. Historical interrelated variations of mercury and aquatic organic matter in lake sediment cores from a subarctic lake in Yukon, Canada: Further evidence toward the algalmercury scavenging hypothesis. Environmental Science and Technology 43:7684-7690.

Streets, D. G., J. Hao, Y. Wu, J. Jiang, M. Chan, H. Tian, and X. Feng. 2005. Anthropogenic mercury emissions in China. Atmospheric Environment 39:7789-7806.

Turetsky, M. R., J. W. Harden, H. R. Friedli, M. Flannigan, N. Payne, J. CROCK, AND L. RADKE. 2006. Wildfires threaten mercury stocks in northern soils. Geophysical Research Letters 33:L16043.1-L16043.

UNEP/AMAP. 2011. Climate change and POPs: Predicting the impacts. Report of the
UNEP/AMAP Expert Group. Secretariat of the Stockholm Convention, Geneva, Switzerland.

Wade, T. L., E. L. Atlas, J. M. Brooks, M. C. Kennicutt II, R. G. Fox, J. Sericano, B. Garcia-Romero, and D. DeFreitas. 1988. NOAA Gulf of Mexico Status and Trends program: Trace organic contaminant distribution in sediments and oysters. Estuaries 11:171-179.

WALKeR, W. 1977. Chlorinated hydrocarbon pollutants in Alaskan Gyrfalcons and their prey. Auk 94:442-447.

WAYland, M., AND A. M. Scheuhammer. 2011. Cadmium in birds. Pages 645-668 in W. N. Beyer and J. P. Meador (Eds.). Environmental Contaminants in Biota. CRC Press, Boca Raton, Florida, USA.

WiedinMeYer, C., AND H. Friedli. 2007. Mercury emission estimates from fires: An initial inventory for the United States. Environmental Science and Technology 41:8092-8098.

Witt, E. L., R. K. Kolka, E. A. Nater, And T. R. WICKMAN. 2009. Forest fire effects on mercury deposition in the boreal forest. Environmental Science and Technology 43:1776-1782.

Zhulidov, A. V., J. V. Headley, D. F. Pavlov, R. D. Robarts, L. G. Korotova, Y. Y. VinNIKOV, AND O. V. ZHULIDOVA. 2000. Riverine fluxes of the persistent organochlorine pesticides hexachlorcyclohexane and DDT in the Russian Federation. Chemosphere 41:829-841. 
- Matz et Al. - 